\title{
SCALING UP THE PRODUCTION AND COMMERCIALIZATION OF TAMARIND FRUIT IN KENYA: THE MISSING VALUE CHAIN LINKS
}

\author{
Wanjala Simon P.O. \\ Kenya Agricultural and Livestock Research Organization - Headquarters \\ P.O Box 57811-00200, Nairobi. \\ E mail: simon.omondi@kalro.org; Tel: +254 717444923
}

\begin{abstract}
There is limited information on Tamarind production, trade and value added products in Kenya. Of late, there is growing interest in the domestic and export markets due to its multiple uses. The objective of this paper is to review existing literature to identify the missing value chain links which may help catalyse the scaling up of production and commercialization of Tamarind. Selected literature and interviews with traders and extension staff in the Coastal Counties were used to collect information for this study. Tamarind fruits are mainly collected in the wild in semi-arid areas of the country and marketed through informal channels. Mombasa is the terminal market for tamarind from Kenya and Uganda, from where domestic consumers and exporters obtain their supplies. Globally, virtually every part of tamarind tree (pulp, seed, leaves, flowers, bark and roots) has either nutritional, industrial or medicinal value. Tamarind fruit contains substantial levels of carbohydrates, proteins, vitamins, minerals and essential amino acids making it potentially useful in addressing wide spread malnutrition. Its anti-oxidant, anti-inflammatory, anti-microbial, antifungal and anti-diabetic properties gives tamarind wider application in conventional and traditional medicine. The findings suggest that scaling up the production and commercialization of tamarind in the country requires both public and private sector investment. The structure of this partnership should consist of the following value chain links: An efficient Seed / seedling system as a source of planting materials; production hubs by farmer associations, government institutions and private farms; aggregation centres for assurance of volumes and quality; processing, value addition and product diversification; an efficient distribution systems of wholesalers and retailers, particularly supermarkets; exporters and consumers. The agenda for further research should include breeding and availing early maturing cultivars demanded by the export market, quality management and value addition technologies.
\end{abstract}

Key Words: Tamarind value chain, scaling-up, production, commercialization

\section{INTRODUCTION}

Tamarind or Tamarindus indica L. of the Fabaceae, subfamily Caesalpinioideae, family Leguminosae (Fabaceae) is an important food in the tropics (Caluwe et al., 2010). Several authors have suggested different geographical areas as the origin of the tamarind tree. Tamarind fruit was at first thought to be produced by an Indian palm, as the name tamarind comes from a Persian word 'tamara-i-hindi', meaning 'date of India' (Morton, 1987; El-Siddig et al., 2006; Rao et al., 2012). However, other authors consider Tamarind native to tropical Africa from Sudan, Ethiopia, Kenya, 
Tanzania, Sudan through the Sahel in West Africa (NAS, 1979). Von Maydel (1986) and Hocking (1993) report Tamarind originated in Madagascar from where it is thought to have been introduced in South East Asia. It grows in more than 50 countries of the world. The major areas of production are in Asian countries like India, Thailand, Bangladesh, Sri Lanka, Malaysia, Indonesia, and in Africa, Mexico, Costa Rica, USA, Brazil and Australia. India is the largest producer and exporter of Tamarind mainly to USA and Europe (Kumar \& Bhattacharya., 2008). It is a multi-purpose tree and almost every part is used either for nutritional, medicinal or industrial value. Some of the most common products produced from Tamarind include juice, pulp, powder, chutney, pickles, sauces, sugar coated candies and tamarind kernel powder (TKP). Tamarind comes in two main varieties; sweet and sour. Sweet tamarind is harvested ripe and usually consumed fresh, while the sour tamarind is usually processed into a range of value added products (El siddig., 2006). The fruit is slightly curved and contain about 55\% pulp, $34 \%$ seed, and $11 \%$ shell, and the fiber in a pod (ElSiddig et al., 2006; Kumar \& Bhattacharya., 2008).

The tamarind tree has the ability to grow in poor soils in semi arid conditions because of their nitrogen fixing capability and withstanding long periods of drought makes them as ideal low input, high yielding trees (Felker, 1981). For instance in Uganda, Buyinza et al (2010) reported that the tamarind tree was found both on farms and in the wild. Ecologically, it combines well with cereal crops. Tamarind regenerates well, and has traditionally been protected during bush clearing by farmers. The trees found on farms were initially in the wild but after clearing land for farming, they were retained as boundary markers, contour hedges or scattered on cropland.

In Kenya, Tamarind fruit value chain is not yet developed since these fruits are mainly found in the wild. Of late, there is growing interest in the domestic and export markets due to its multiple uses. There is very limited documentation on the production and marketing of Tamarind in Kenya and information is only known to a few market actors (Betser, 1999). The objective of this paper is to review existing information to identify the missing value chain links which may help catalyse the scaling up of production and commercialization of Tamarind in Kenya.

\section{METHODOLOGY}

Selected literature review and insights from interviews with traders and extension staff in the Coastal Counties of Mombasa, Taitta Tavetta, Kwale and Kilifi, and a recent report on rapid appraisal of underutilized fruit products in urban markets in Kenya (Wanjala, 2018) are used in the discussion and identification of missing value chain links in the country.

\section{RESULTS AND DISCUSSION}

\section{Production areas and characteristics}

Tamarind trees are found mainly in the wild woodlands in dry areas of Kitui, Tharaka Nithi, Baringo, West Pokot, Turkana, Homa Bay, Taita Taveta, Kwale and Lamu Counties (Betser, 1999; Wanjala survey report., 2018). Betser (1999) reports that in Tharaka, Tamarind is harvested between July and October. Tamarind tree starts fruiting (Figure 1) from 10-14 years (Morton, 
1999; Buyinza et al., 2010) and can produce up to $225 \mathrm{Kg}$ of tamarind in a season (FAO, 1998). In India, improved improved cultivar in Tamil Nadu, yields about $263 \mathrm{~kg} / \mathrm{tree}$. (Rao et al., 2012). Organized production has not been documented in Kenya. Kenya Agricultural and Livestock Research Organization (KALRO) has established nurseries for seedlings at its centres in Muguga, Katumani, Matuga, Kakamega, Alupe, Perkerra and Kibos (Figure1). These nurseries will be used as source of planting materials by farmers in the country. Interviews carried out with County government extension staff indicate that Tamarind has not yet been prioritised as a farm crop in Kenya neither is it documented in the Ministry of Agriculture reports. Given the increasing global prominence of Tamarind as an export tree crop, the production stage of the value chain should move from the wild (Figure 2) to on-farm cultivation and strengthened through promoting farm production of both the sweet and sour tamarind varieties. Both individual and institutional farms, namely Agricultural Training Centres (ATCs), Kenya Forestry Service, Kenya Forestry Research Institute, Prisons and schools could be used as production hubs. These farms should also be linked to the necessary support services, namely, access to an efficient tamarind seed / seedling supply system, Good Agricultural Practices (GAPS), post-harvest handling and value addition technologies, financing, and most importantly, farm certification. Productivity and commercialization of tamarind for domestic and export markets could further be augmented through national and County government policy frameworks, development assistance programs, private sector investment and researchable issues such as early maturing varieties, genetic conservation and desirable market traits. These interventions will be useful in protecting the tamarind tree from the threat of extinction due to human activities such as charcoal burning and timber common in semi arid ecosystems.

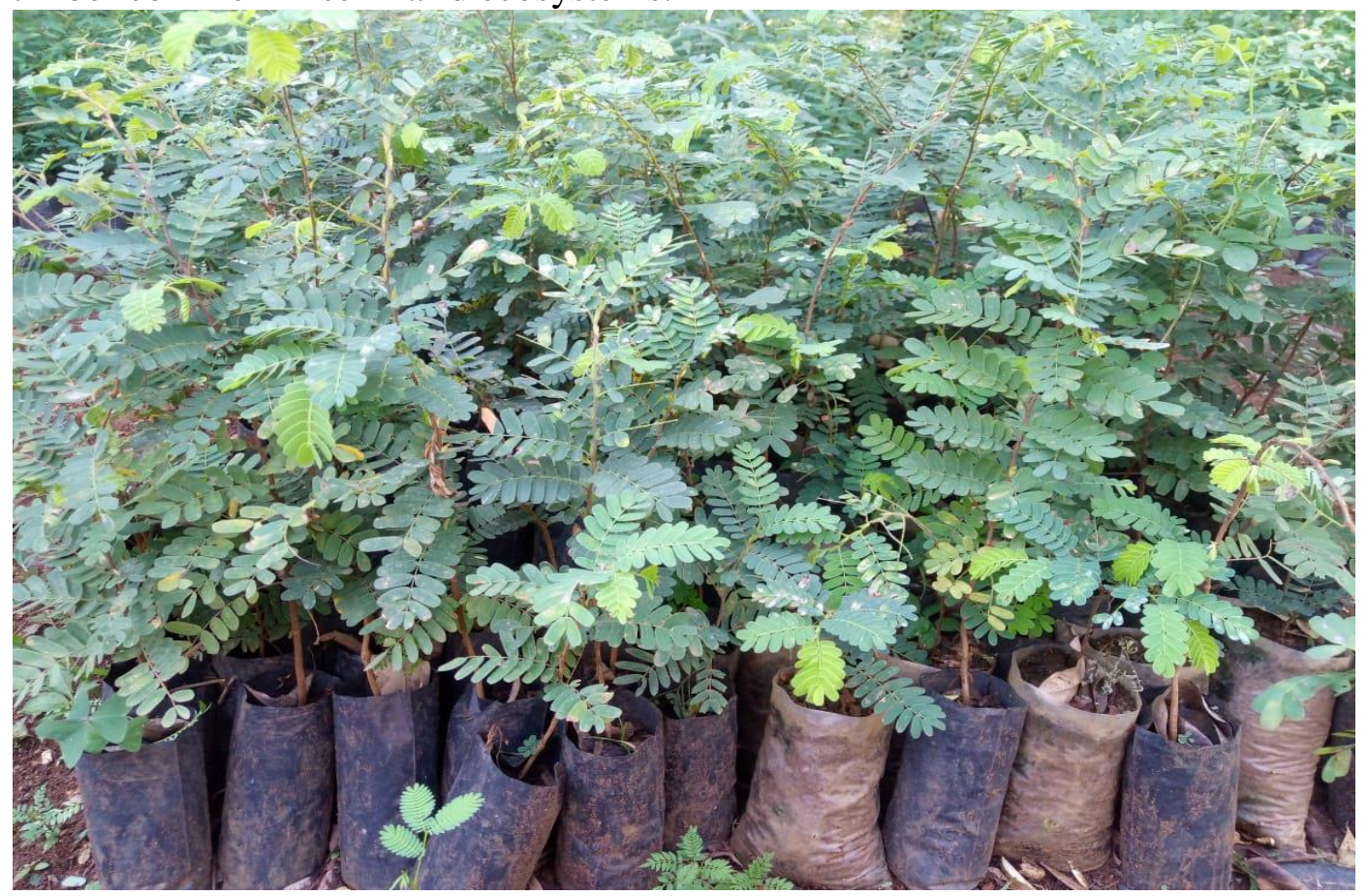

Figure 1: Tamarind seedlings in a Nursery at KALRO 


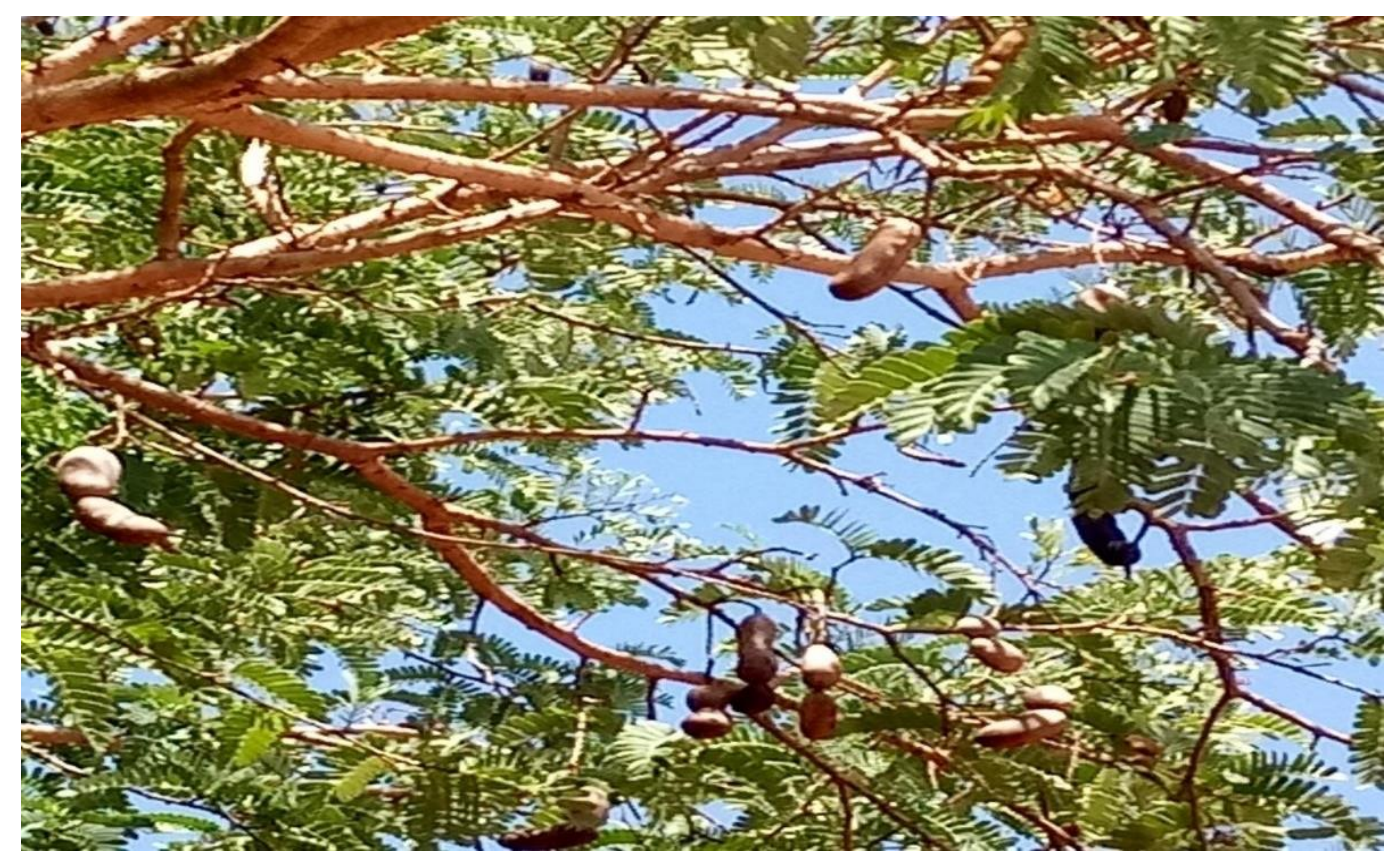

Figure 2: Tamarind tree with mature pods in Taita Tavetta wood lands Kenya

\section{Collection / bulking}

In Kenya, the pods are harvested when the skin is brittle and the pulp is red-brown in colour and sticky in texture. Interviews carried out with traders revealed that Tamarind value chain comprises farmers, assemblers, traders, transporters, brokers, wholesalers, retailers, exporters and consumers (Figure 3). The fruits are collected from Locations in Kenya as well as from Eastern and Northern Uganda and sold in local markets and some specialty super markets. The largest market and destination for Tamarind trade in Kenya is in Kongowea, Mombasa. The scattered nature of these sources makes it more difficult to aggregate trade volumes and hence with organized production, the need for aggregation centres within production hubs will be an important link in the value chain.

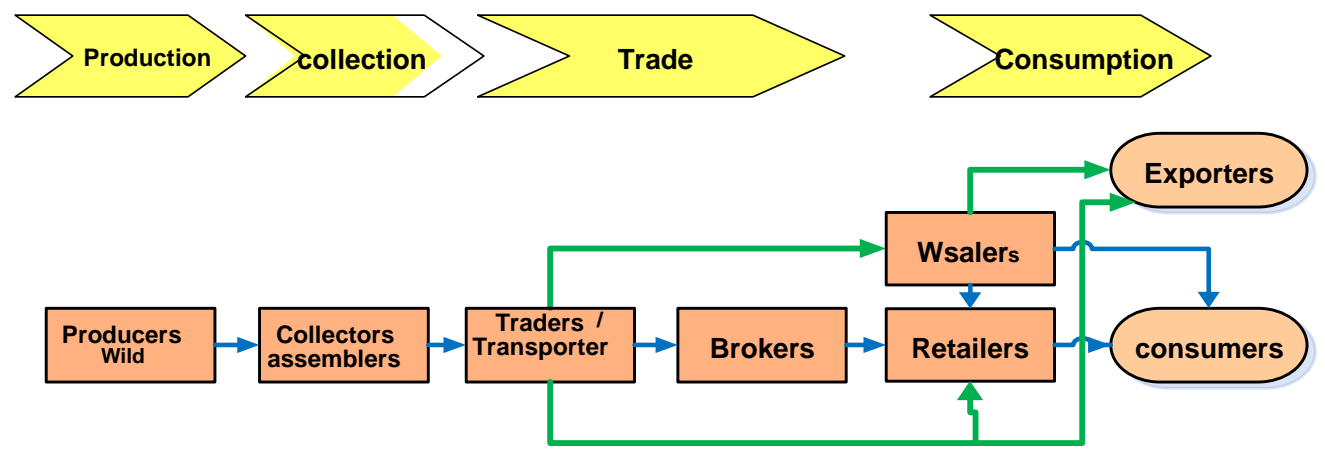

Figure 3: Tamarind value chain in Kenya 


\section{Post-harvest handling}

The ripe pods vary in length from around 2-17 $\mathrm{cm}$ and in diameter from 2-3.2 cm with 1-12 seeds (Morton, 1999). After harvesting pods, the brittle skin are peeled off. Betser (1999) and traders interviewed report that after harvesting the pods, four grades of tamarind fruit are prepared and bagged both either on farm or at collection centres, according to orders. There are:

- Grade 1: dehusked, de-seeded and no fibres

- Grade 2: dehusked, de-seeded with fibres

- Grade 3: dehusked, with seed and fibres

- Grade 4: with husk, seed and fibres.

Most of the tamarind traded locally is of grade 3 quality (figure 4). However, export market requires grade 2 (dehusked, de-seeded with fibres). Dehusked tamarind with seed stores for up to six months before it is attacked by weevils, whereas de-seeded tamarind can be stored for around 2 years (Betser., 1999). Handling can have an impact on health and on entry into export markets. For instance, the U.S. government (FDA, 1999) keeps a list of organisations which are permitted to import tamarind (fresh and processed) due to the filth (insect, rodent, bird, cat/dog damage, mould) commonly found in tamarind. A competitive and market-oriented tamarind value chain in Kenya should have a traceability, safety and quality assurance system in place.

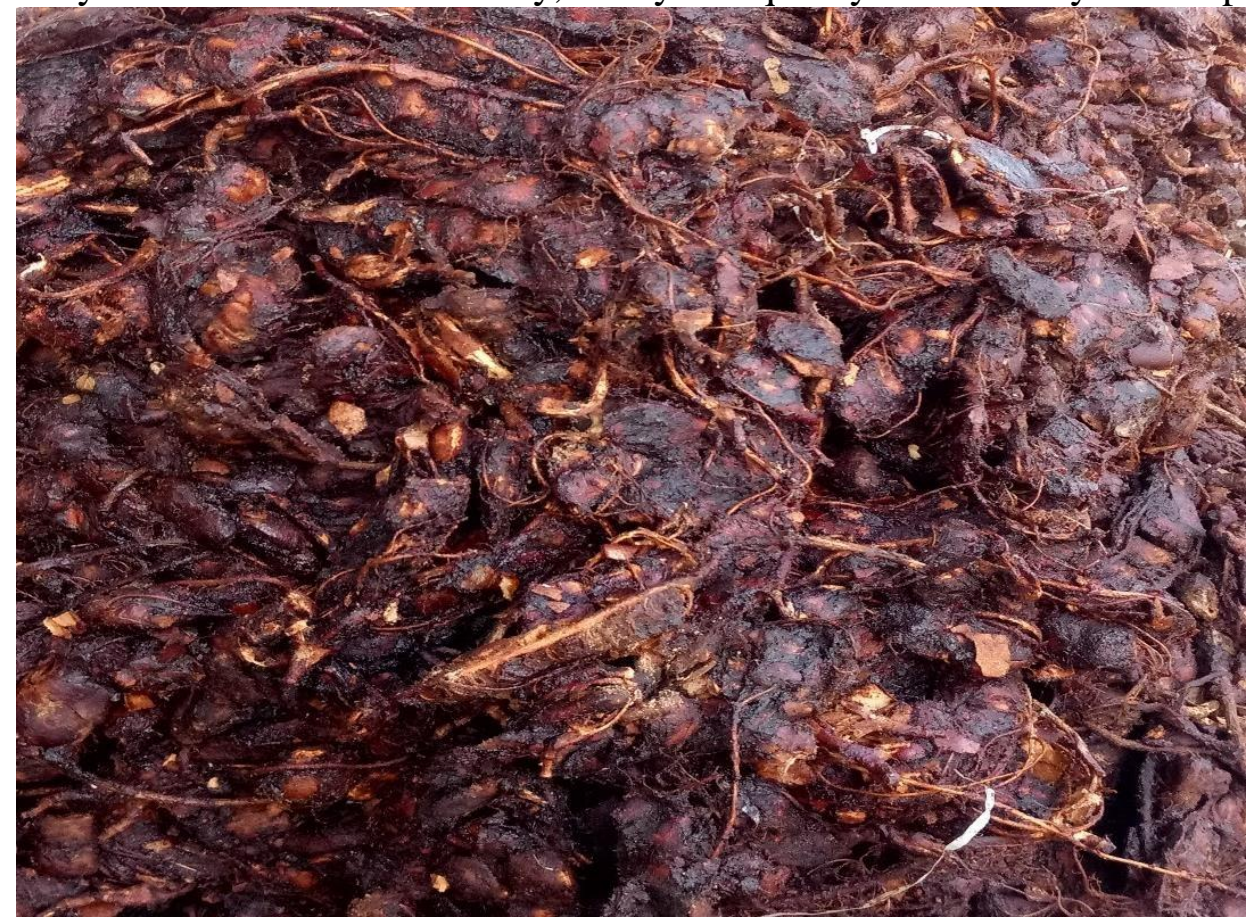

Figure 4: Dehusked Tamarind with seed and fibres

\section{Value addition and processing}

There is very little value addition and industrial processing that takes place in the country apart from Tamarind juice. Tamarind fruits are sold at Kongowea municipal market where both whole sale and retail takes place, while juices are sold in some specialty Mombasa restaurants (Tarboush, Barka cafe, Little chef, Muvita cafe). Besides tamarind juice, there are many other value added products and uses of various parts of Tamarind tree (Caluwe et al., 2010; Rao et al., 2012) which 
actors in the Tamarind value chain in Kenya could target. Product diversification, quantity, quality and branding should be the focus for locally produced Tamarind.

\section{Existing and potential markets}

Tamarind is traded almost entirely through informal channels. The traders interviewed revealed that in Mombasa, Tamarind fruits are also exported to the Middle East, Italy, India, Thailand, Philippines, Somalia and Tanzania from where value added products such as flavours, sauce, spice, flour, sweet chutney, kernel oils are made. However, official Statistics on trade volumes are scanty. Lack of information is a bottleneck along the tamarind marketing chain. Traders mentioned that they found it difficult to identify exporters, particularly those traders who do not have coastal networks. Hence the need for vertical and horizontal linkages among actors to share information especially on quantity, quality and price is paramount.

\section{Tamarind products and uses}

Pulp: The pulp which accounts for $55 \%$ of the fruit has various uses in many countries. It is eaten fresh; used in preparation of drinks and alcoholic beverages, for seasoning, as a food component, to flavour confections, curries and sauces, and is a main component in juices and certain beverages and can also be processed into jam and sweets (El-Siddig et al., 2006; Caluwe et al., 2010). Seeds: Tamarind seed is a by-product of the tamarind pulp industry in the form of tamarind kernel powder (TKP), is used as a sizing material in the textile, paper, and jute industries and its gelling cum adhesive characteristics of the decorticated seed powder are used in food and pharmaceutical industries (El-Siddig et al., 2006; Kumar and Bhattacharya, 2008; Caluwe et al., 2010). Tamarind seeds are reported to give amber-coloured oil, free of smell and sweet to taste, and is also used in varnishes and paints. Flour from the seed may be made into cake and bread.

Roasted seeds are claimed to be superior to groundnuts in flavour (ICRAF, 2007).

Seed testa: The testa is reported to contain tannin and colouring matter used in dyeing and tanning has been suggested (El-Siddig et al., 2006).

Leaves and Flowers: Tamarind flowers and leaves can be eaten as vegetables and are prepared in a variety of dishes (ICRAF, 2007). Tamarind trees growing in woodlands are often eaten by wild animals, such as camels, elephants or giraffes, for which tamarind is a preferred plant, perhaps because of its high crude protein content (El-Siddig et al., 2006). In the southern states of India, cooked seeds of tamarind are fed to draught animals (ICRAF, 2007)

Bark: The bark is rich in tannins of up to $70 \%$, and is used in the tanning industry. The bark is used for tanning hides and in dyeing (Morton, 1987; El-Siddig et al., 2006).

\section{Nutritional value of Tamarind fruit}

Tamarid fruit is rich in energy, carbohydrates, protein, vitamins and minerals (Table 1).

The fruit has a high content of Vitamins $\mathrm{B}_{1}, \mathrm{~B}_{2}$ and $\mathrm{B}_{3}$ as well as folate. It is also a good source of magnesium (26\%), iron (22\%), Phosphorus (16\%) and potassium (13\%) as well as zinc (1\%). 


\section{Table 1: Nutritional value of Tamarind fruit per $100 \mathrm{~g}$}

\begin{tabular}{|l|l|}
\hline Energy & $239 \mathrm{kcal}(1,000 \mathrm{~kJ})$ \\
\hline Carbohydrates & $62.5 \mathrm{~g}$ \\
\hline Sugars & 57.4 \\
\hline Dietary fiber & $5.1 \mathrm{~g}$ \\
\hline Fat & $0.6 \mathrm{~g}$ \\
\hline Protein & $2.8 \mathrm{~g}$ \\
\hline Vitamins & Quantity (\%DV) \\
\hline Thiamine (B1) & $37 \%(0.428 \mathrm{mg})$ \\
\hline Riboflavin (B2) & $13 \%(0.152 \mathrm{mg})$ \\
\hline Niacin (B3) & $13 \%(1.938 \mathrm{mg})$ \\
\hline Pantothenic acid (B5) & $3 \%(0.143 \mathrm{mg})$ \\
\hline Vitamin B6 & $5 \%(0.066 \mathrm{mg})$ \\
\hline Folate (B9) & $4 \%(14 \mu \mathrm{g})$ \\
\hline Choline & $2 \%(8.6 \mathrm{mg})$ \\
\hline Vitamin C & $4 \%(3.5 \mathrm{mg})$ \\
\hline Vitamin E & $1 \%(0.1 \mathrm{mg})$ \\
\hline Vitamin K & $3 \%(2.8 \mu \mathrm{g})$ \\
\hline Minerals & Quantity (\%DV \\
\hline Calcium & $7 \%(74 \mathrm{mg})$ \\
\hline Iron & $22 \%(2.8 \mathrm{mg})$ \\
\hline Magnesium & $26 \%(92 \mathrm{mg})$ \\
\hline Phosphorus & $16 \%(113 \mathrm{mg})$ \\
\hline Potassium & $13 \%(628 \mathrm{mg})$ \\
\hline Sodium & $2 \%(28 \mathrm{mg})$ \\
\hline Zinc & $1 \%(0.1 \mathrm{mg})$ \\
\hline Source: USDA 2017 \\
\hline
\end{tabular}

Source: USDA, 2017

\section{Essential amino acid profile of Tamarind}

Amino acid profiles of tamarind show that the proteins contain fairly balanced essential amino acid levels (Table 2). In terms of protein content and WHO standards, tamarind seeds score well for 3 of the 8 essential amino acids. Tamarind seeds could therefore be used as a less expensive source of protein to help alleviate protein malnutrition which is widespread in many developing countries (Siddhuraju et al. (1995) cited in El-Siddig et al., 2006)

Table 2: Essential Amino acid profile of Tamarind compared to WHO Ideal standard

\begin{tabular}{|l|l|}
\hline Amino acid & Tamarind seed /Ideal x $100 \%$ \\
\hline Threonine & 75.00 \\
\hline Valine & 82.00 \\
\hline
\end{tabular}




\begin{tabular}{|l|l|}
\hline Methionine + cysteine & 140.00 \\
\hline Leucine & 90.00 \\
\hline Isoleucine & 97.50 \\
\hline Phenylanine + tyrosine & 160.00 \\
\hline Lysine & 110.91 \\
\hline Tryptophan & 25.00 \\
\hline
\end{tabular}

Source: Glew at al., 1997.

\section{Health benefits: Use in medicine}

\section{Anti-oxidant activity}

The human body produces many free radicals due to metabolic activity which could predispose inflammatory diseases and therefore anti-oxidants are important in cleaning the system from these radicals. Tamarind seeds, leaves and flowers have been shown to have high content of phenolic compounds with potential for many biological uses (Soong et al., 2004; Tsuda et al., 2004). Martinello et al. (2006) reports the potential of tamarind extracts in diminishing the risk of atherosclerosis development in humans, which is the main contributor for the pathogenesis of myocardial and cerebral infarction.

\section{Anti-inflammatory activity}

Anti-inflammatory properties of tamarind fruit pulp were reported by Rimbau et al. (1999) and could have to potential to address the abnormal accumulation of elastase, a serine proteinase from human neutrophil, which causes acute and chronic inflammation diseases (Bernstein et al. (1994) cited in Fook et al., 2005).

\section{Anti-microbial activity}

Al-Fatimi et al (2007) showed that extracts from T. indica flowers showed antibacterial activity against four bacteria (Staphylococcus aureus, Bacillus subtilis, Escherichia coli and Pseudomonas aeruginosa). These results could have important implications in medical use. Other useful properties of Tamarind reported include: Anti-fungal (El-Siddig et al., 2006), Anti helmintic ( Mackeen et al. (1997) cited in El-Siddig et al., 1999), Anti-viral for water melon, cow pea and tobacco mosaic virus (Chapman (1984) cited in El-Siddig et al., 1999, Anti diabetic (Maitin et al. (2004) cited in El-Siddig et al., 2006), Anti nematodal and Anti molusciscidal ((Imbabi \&Abu-Al-Futuh (1992a) cited in El-Siddig et al., 2006). 


\section{Traditional medicine}

Tamarind is used in herbal medicine in many parts of the world as shown in Table 3.

Table 3: Traditional uses of Tamarind

\begin{tabular}{|l|l|l|l|}
\hline Country & Tamarind part used & Herbal use & References \\
\hline India & Seeds & $\begin{array}{l}\text { Anti-diabetic; diarrhea; oil for } \\
\text { pimples, hair dressing }\end{array}$ & El-Siddig et al.( 2006) \\
\hline Indonesia & Leaves, pulp & $\begin{array}{l}\text { Laxative; hearmohoids; antiseptic; } \\
\text { dysentery; throat infections; intestinal } \\
\text { worms }\end{array}$ & $\begin{array}{l}\text { El-Siddig } \text { et al.( 2006); } \\
\text { Morton (1987) }\end{array}$ \\
\hline Brazil & Leaves & $\begin{array}{l}\text { Liver ailments; cardiac and blood } \\
\text { sugar problems }\end{array}$ & El-Siddig et al.( 2006) \\
\hline West Africa & Leaves & Rheumatism; ulcers & El-Siddig et al.( 2006) \\
\hline Philipines & Leaves, bark, flower & $\begin{array}{l}\text { Cough remedy; Eye infections; } \\
\text { wounds }\end{array}$ & El-Siddig et al.( 2006) \\
\hline & $\begin{array}{l}\text { Rootsdigestive tract } \\
\text { problems, chest }\end{array}$ & & Morton (1987) \\
\hline
\end{tabular}

Source: Compiled from Caluwe et al., (2010)

\section{Opportunities for Research and development}

A productive and market-oriented tamarind value chain in Kenya should be driven by a focused research agenda. Some of the key research interventions based on the findings in this paper may include:

- Mapping and nutritional analysis of varieties from different ecological zones

- Conservation of tamarind germplasm.

- Seed selection and establishment of an efficient Seed system.

- Biotechnological tools to enhance multiplication of planting materials.

- Tamarind agronomic practices.

- Research into early maturing sweet/ sour cultivars.

- Value added products and value addition technologies.

- Market research and economic analysis at different stages of the value chain

\section{Way Forward}

Based on the findings in this paper, figure 5 illustrates a potential structure for upgrading the tamarind value chain in the country. The structure should consist of the following value chain links: An efficient Seed / seedling system as a source of planting materials; production hubs by farmer associations, government institutions and private farms; aggregation centres for assurance of volumes and quality; processing, value addition and product diversification; an efficient distribution systems of wholesalers and retailers, particularly supermarkets; exporters and consumers. 


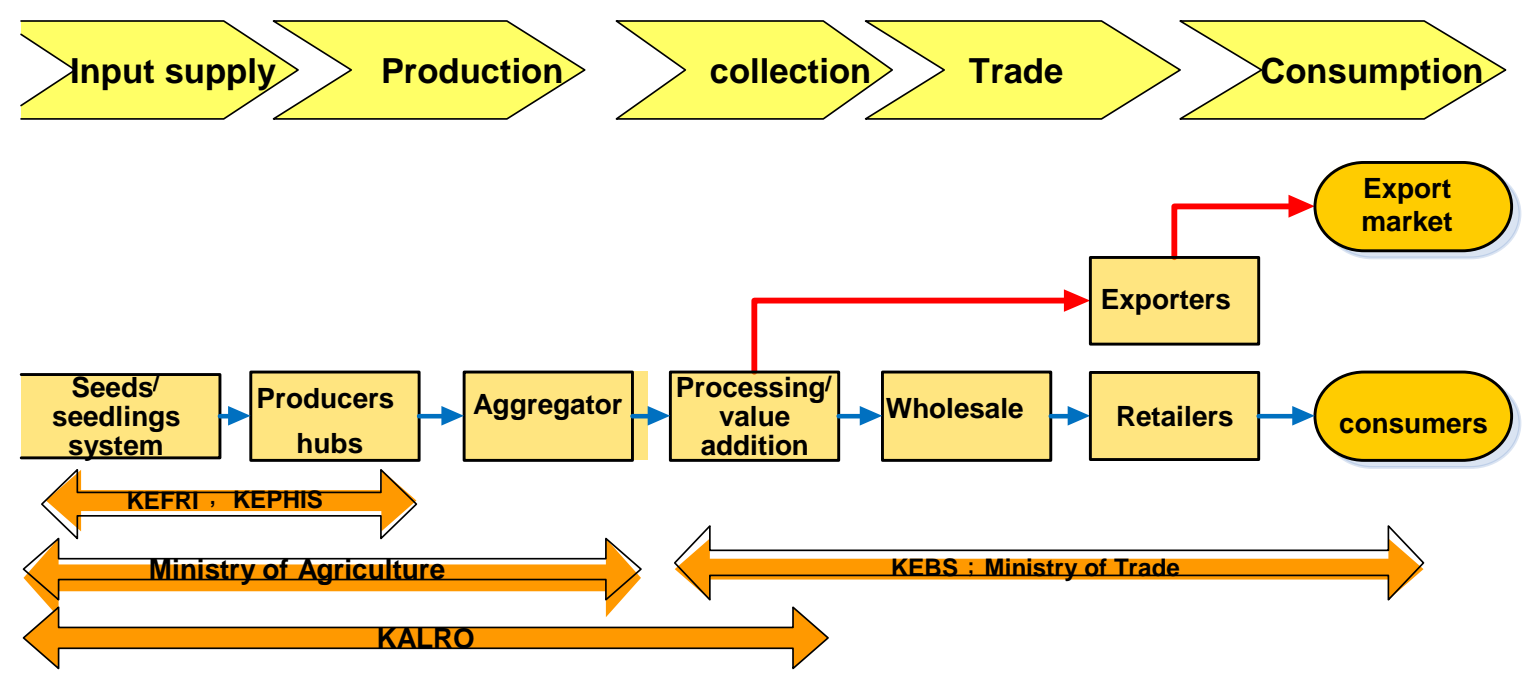

Figure 5: Envisioned Tamarind value chain in Kenya

\section{CONCLUSION}

There is limited information on Tamarind production, trade and value added products in Kenya. Tamarind fruits are mainly collected in the wild in semi arid areas of the country and marketed through informal channels. Mombasa is the terminal market for tamarind from Kenya and Uganda, from where domestic consumers and exporters obtain their supplies. Globally, virtually every part of tamarind tree (pulp, seed, leaves, flowers, bark and roots) has either nutritional, industrial or medicinal value. Tamarind fruit contains substantial levels of carbohydrates, proteins, vitamins, minerals and essential amino acids making it important in addressing wide spread malnutrition especially in semi arids areas. Its anti-oxidant, anti-inflammatory, anti-microbial, anti-fungal and anti-diabetic properties gives tamarind wider application in conventional and traditional medicine. Scaling up the production and commercialization of tamarind in the country requires both public and private sector investment. The structure should consist of the following value chain links: An efficient Seed / seedling system as a source of planting materials; production hubs by farmer associations, government institutions and private farms; aggregation centres for assurance of volumes and quality; processing, value addition and product diversification; an efficient distribution systems of wholesalers and retailers, particularly supermarkets; exporters and consumers.

\section{ACKNOWLEDGEMENT}

The author is greatly indebted to various authors for use of their scholarly works in this review. Tamarind traders in the Coastal Counties of Mombasa, Taitta Taveta, Kilifi and Kwale and the respective County departments of Agriculture are highly appreciated for providing insights on Tamarind value chain. The field study was funded by USAID through the KALRO-USAID FtF IARD project.

\section{REFERENCES}


Al-Fatimi M., Wurster M., Schröder G. and Lindequist U. (2007). Antioxidant, antimicrobial and cytotoxic activities of selected medicinal plants from Yemen. Journal of Ethnopharmacology, 111, 657-666.

Betser L. (1999). Rapid Reconnaissance Market Survey on Tamarind in Kenya. ICRAF. Buyinza M and Badru L. (2010). Economic valuation of Tamarind (Tamarindus Indica L ) Production System : Green Money from Drylands of Eastern Uganda. Small-Scale Forestry. DOI:10.1007/s11842-010-9118-y.

Caluwe E.D, Halamova K. and Van Damme P. (2010). Tamarindus indica L. - A review of traditional uses, phytochemistry and pharmacology. AFRIKA FOCUS, Vol 23, 1:53-83.

El-Siddig K., Ebert G. and Lüdders P. (1999). Tamarind (Tamarindus indica L.): a Review on a Multipurpose Tree with Promising Future in the Sudan. Journal of Applied Botany - Angewandte Botanik, 73, 202-205.

El-Siddig K., Gunasena H.P.M., Prasa B.A., Pushpakumara D.K.N.G., Ramana K.V.R., Vijayanand P. and Williams, J.T. (2006). Tamarind - Tamarindus indica L. Fruits for the future 1. Southampton Centre for Underutilized Crops, Southampton, UK, 188p.

FAO (1988). Fruit Bearing Trees. Technical notes. FAO-SIDA Forestry Paper 34:165-167.

Felker P. (1981). Uses of tree legumes in semiarid regions. Economic Botany, 35:174-185. Fook J.M.S.L.L., Macedo L.LP., Moura G.E.D.D., Teixeira F.M., Oliveira A.S., Queiroz A.F.S. and Sales M.P. (2005). A serine proteinase inhibitor isolated from Tamarindus indica seeds and its effects on the release of human neutrophil elastase. Life Sciences, 76, 2881-2891.

FDA. (1999). Import Alert. IA2107. FDA, USA. Website:

http://www.fda.gov/ora/fiars/ora_import_ia2107.html

Glew R.H., VanderJagt D.J., Lockett C., Grivetti L.E., Smith G.C., Pastuszyn A. and Millson M. (1997). Amino Acid, Fatty Acid, and Mineral Composition of 24 Indigenous Plants of Burkina Faso. Journal of Food Composition and Analysis, 10, 205-217.

Hocking D. (1993). Trees for Drylands. Tamarindus indica L., Family Leguminosae: Caesalpinoideae. Oxford and IBH Publishing Co., New Delhi, 305-7.

http://www.indianspices.com.

ICRAF (2007). World Agroforestry Centre. ICRAF Agroforestry Tree Database: Tamarindus indica L., URL http:// www.worldagroforestrycentre.org.

Imbabi E.S. and Abu-al-futuh I.M. (1992). Investigation of the molluscicidal activity of Tamarindus indica L. International . Journal of. Pharmacology, 30(2): 157-60.

Martinello F., Soares S.M., Franco J.J., Santos A.C, Sugohara. A., Garcia S.B., Curti C. and Uyemura, S.A. (2006). Hypolipemic and antioxidant activities from Tamarindus indica L. pulp fruit extract in hypercholesterolemic hamsters. Food and Chemical Toxicology, 44, 810-818.

Morton J. (1987). Tamarind. In: Fruits of warm climates, Morton, J.F. (ed.). Miami, USA, p. 115121.

Morton J. (1999). Tamarind. In: Fruits of warm climates p115-121. Miami, Florida. Website: http://www..hort.purdue.edu/newcrop/morton/tamarind.html

NAS (1979). Tropical Legumes: Resources for the Future. Washington DC, 117-21.

Kumar C.S and Bhattacharya S. (2008) Tamarind Seed: Properties, Processing and Utilization.

Critical Reviews in Food Science and Nutrition, 48, 1-20.

Rao S.Y. and Mathew, MK. (2012) Tamarind. Woodhead Publishing Limited. Cambridge. Rimbau V., Cerdan C., Vila R. and Iglesias J. (1999). Antiinflammatory Activity of Some Extracts from Plants used in the Traditional Medicine of North-African Countries (II). Phytotherapy Research, $13,128-132$. 
Soong Y.Y. and Barlow P.J. (2004). Antioxidant activity and phenolic content of selected fruit seeds. Food Chemistry, 88, 411-417.

Tsuda T., Watanabe M., Ohshima K., Yamamoto A., Kawakishi S. and Osawa T. (1994). Antioxidative Components Isolated from the Seed of Tamarind (Tamarindus indica L.). Journal of Agricultural and Food Chemistry, 42, 2671-2674.

USDA. (2017). Nutritional values of Tamarind fruit. US department of Agriculture.

Von maydell M. J (1986). Trees and Shrubs of Sahel; Their Characteristics and Uses. Deutsche. Geseuschft Fuer Techhische Zusammenarboit, Eschborn, Germany, 111.

Wanjala S.P.O. (2018). Documentation and rapid appraisal of underutilized fruit products in urban markets in Kenya. Field Report. Kenya Agricultural and livestock Research organization. 